\title{
USING SOCIAL MEDIA WEBSITES TO PROMOTE TERRORISM ISSUES- A STUDY OF SITE USERS' SAMPLE
}

\author{
Dr. Abdul Malik Al-Danani ${ }^{1}$, Dr. Ryadh Ben Amor ${ }^{2}$ \\ ${ }^{1,2}$ Associate Professor, Emirates College of Technology, Abu Dhabi, United Arab Emirates
}

DOI: https://doi.org/10.29121/granthaalayah.v8.i5.2020.62

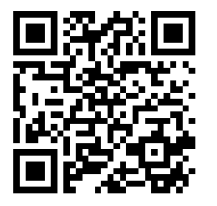

Article Type: Research Article

Article Citation: Dr. Abdul Malik AlDanani, and Dr. Ryadh Ben Amor. (2020). USING SOCIAL MEDIA WEBSITES TO PROMOTE TERRORISM ISSUES. International Journal of Research GRANTHAALAYAH, 8(5), 55-77. https://doi.org/10.29121/granthaa layah.v8.i5.2020.62

Received Date: 09 May 2020

Accepted Date: 26 May 2020

Keywords:

Social Media

Terrorist Groups

Terrorism Issues

\begin{abstract}
Modern communication technologies have contributed to the emergence of social media, facilitating the transmission of information, ideas and opinions, and the formation of groups of common interests. Social media has provided fertile ground for non-state groups and terrorism is one of their most important incarnations. This scientific study is based on the theory of "sociology of use", which revolves around the way of perceiving the action and the connotations of technological innovations in society. The purpose of this study is to discover the use of social media websites to promote terrorism issues. Which has become a serious reality imposed on members of communities worldwide, using social networking techniques in the promotion of terrorist groups. In addition to identifying the vision carried by the users of social sites on terrorism issues, and how they exploit their common potential with terrorist groups?
\end{abstract}

\section{INTRODUCTION}

Is there an implicit relationship between modern technologies and the social impact on users?

The purpose of this study is to discover the use of social media websites to promote terrorism issues. Which has become a serious reality imposed on members of communities worldwide, using social networking techniques in the promotion of terrorist groups. In addition to identifying the vision carried by the users of social sites on terrorism issues, and how they exploit their common potential with terrorist groups?

\section{THE METHODOLOGICAL FRAMEWORK FOR RESEARCH}

\subsection{INTRODUCTION}

Modern society is experiencing rapid developments in the field of communication, accompanied by changes in the methods of production, distribution and reception of information, due to new technologies and digital media, which has led to the emergence of new technologies. features and functions, the most important. interactive and important multiple content features and functions, the most important of which are interactive and various content.

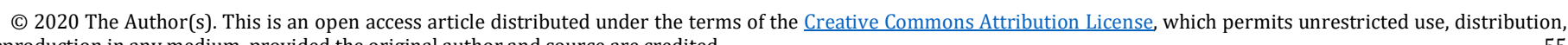
and reproduction in any medium, provided the original author and source are credited. 
Social networking sites are among the main communication media combining these features. They have spread widely over the Internet and have doubled the number of users in every country in the world. Facebook, for example, is used by more than one billion users worldwide. According to the statistics published in 2016 [1], such sites have become useful and harmful sources of information and ideas.

Terrorism issues have become deeply embedded in the realities of the situation of local and international communities, threatening the interior security and stability of states and limiting the effectiveness of development plans in their various fields. Social media technologies have been exploited to promote terrorism and domestication of minds with destructive and extremist perverse ideas, to convince subscribers and browsers of these sites of the ideas adopted by those who promote them.

Thus, social networking sites have offered terrorists an open space to promote their ideas and the terrorist problems they adopt in their intellectual ideology and call for its implementation, for example by attracting fighters from around the world under allegations of the establishment of the Islamic State, jihad, etc.

\subsection{PROBLEMATIC OF RESEARCH}

Previous scientific studies have shown that the use of communication sites increases the formation of social interaction, and since the communication space is an "open" area, the variables in the use of social sites are related to the general development of societies, as they are not static in nature, that is, social forms are changing constantly.

Modern means of communication have contributed to the emergence of social media, facilitating the transmission of information, ideas and opinions, as well as the formation of common interest groups, beyond the control of traditional media. Social networking sites have become fertile ground for non-state groups and terrorism is one of the most important incarnations.

Hence, the main motivation of our implementation of this study is to answer the following three key questions:

- What are the limits and the nature of the use of social networking sites in the promotion of terrorism?

- Have these sites been used to spread the ideas of terrorists?

- Have social media contributed positively to the problems of terrorism?

\subsection{THE IMPORTANCE OF THE STUDY}

This study seeks to identify the limits and the nature of the use of social networking sites capabilities in promoting terrorism issues, as well as their impact on the knowledge formation of community members and their attitude to the regard to terrorist issues. The importance of this study is that it illuminates one of the most important and frequent topics of nowadays. Whereas, terrorism and bloody conflicts are among the most serious and widespread problems through various national, Arab and international means of communication and social networks.

\section{Importance Can Be Summarized as Follows:}

- The study focuses on the axis of employing social networking sites in the process of communication, and the promotion of terrorism issues and the impact on members of society and how to address the issues of terrorism.

- The study highlights one of the hottest and most current topics, where social networking sites play a serious role in promoting issues of terrorism and provoking bloody conflicts, since they combine the characteristics of personal and public communication to touch the members of society and promotes their addressed problems.

\subsection{OBJECTIVES OF THE STUDY}

This study aims to reveal the possibility of using social networking sites to promote the problems of terrorism, which has become a serious reality imposed on members of societies around the world, this by identifying the use of network sites in the promotion of terrorism-related issues, as well as the different areas and dimensions of this relationship. In addition to identifying the view that social sites deal with issues related to terrorism and how they 
are used and exploited by terrorist groups to propagate their deviant thoughts? And can social media contribute positively to the fight against the problems of terrorism?

\subsection{QUESTIONS OF THE STUDY}

This study seeks to answer many questions about the role played by social networking sites in promoting terrorism and spreading deviant ideas. These questions include:

1) To what extent did the public sample for the study use social networking sites?

2) To what extent are social media interested in covering terrorism issues?

3) What social sites are the most promoting for terrorism issues?

4) Do social sites present the problems of terrorism as they are, or do they manipulate them and give them another image?

5) Does the coverage of terrorist cases by social media vary according to the direction and trends of the social web site?

6) To what extent are social media sites committed to dealing with terrorist issues with professional ethics?

\subsection{STUDY APPROACH}

This study is a descriptive study that was used in the implementation of the survey method by taking the advice of a sample of social media users using the survey or the so-called questionnaire, which means "a set of questions designed to collect the necessary data on the problem under study (Alserafi, 2002: p 115). [2]

\subsection{STUDY LIMITS}

- Geographic framework: The spatial boundaries of the study were limited to Yemen and Tunisia.

- Age Framework: Includes the age group (from 25 to 55 years).

- Thematic framework: The function of social networking sites in promoting terrorism issues.

- Time frame: Deadlines have been limited in 2017, due to the increase in terrorist acts.

\subsection{STUDY POPULATION}

The study population is a random sample of social media users in the Republic of Yemen and the Republic of Tunisia. The researchers selected a random sample of 280 people of both sexes.

The questionnaire is a tool for collecting data from respondents. It contains a series of questions intended to collect the necessary data on the research problem studied [3]. It aims to obtain answers to written questions in a form prepared for that purpose, to which the respondent gives answers [4].

\subsection{STUDY DATA COLLECTION TOOL}

After identifying the research problem and formulating it according to the questions the study seeks to answer, the researchers designed the questionnaire and distributed it "electronically" to the sample members, after presenting it to a group of colleagues for the purpose of scientific arbitration of its content. The link has been sent to the sample members to access the page and participate electronically. This electronic method was able to overcome the obstacle of geographical distance by means of electronic correspondence, as result 280 persons responded to the questionnaire.

The questionnaire included two axes:

Axis 1: Basic data illustrating the demographic characteristics of the sample members, in terms of gender, age, occupation and scientific level.

Axis 2: basic information on the use of social networking sites in the promotion of terrorism issues. 


\subsection{PREVIOUS STUDIES}

The researchers examined many previous studies of social networking sites and their multiple effects, including studies of social networking sites and their applications, some prepared by postgraduate researchers and others published in peer-reviewed journals. It was noted that some of the previous studies dealt with research ideas that are close to our study or that they are partially addressed. Among these studies*:

The study (Ridha Abdul Wajid Amin 2016) [5]aimed to identify the role of Twitter and blogging campaigns through social networking sites in the processes of cultural development, and the extent to which social networks are employed To make positive effects on users towards the Year of the Prophet of Islam Muhammad "Peace be upon him", and the way to interact with his topics. The study reached many conclusions, most notably: that more than half of the sample of users of social networking sites are keen to employ these sites by calling by introducing the Prophet or establishing a dialogue with friends and followers of their pages and accounts of special interests, about the prophet and his biography and his creativity and virtues. Each social networking site has a differential advantage over other sites, some are interested in the exchange of texts, others focus on the image and a third focuses on video files, including what combines forms of multimedia, to convey the media message, as well as the most Social media using the definition of Prophet Muhammad, was Facebook, which came first.

The study (Sadeq Rabah, 2016) [6] showed the importance of critical thinking in the rational management of rumors on social networks and studied the implications of the practice of critical thinking on the rationality of the management of rumors in social networks. social networks. The study has yielded many results, including: the existence of a technological and social mechanism based on the promotion and consolidation of the critical thinking of social media users, overcomes many misinformation and manipulation, especially during crises and disasters, to multiply the rumors during these events and to flee for the lives of individuals easily and conveniently. The second approach is based on the idea of allowing users to collectively think, understand and deal with conceptual and controversial issues, such as decision-making, environmental management and various social problems, such as disclosure of rumors.

The 2015 Study of (Faten Abdelrahman) [7] sought to identify the nature and size of Egyptian expatriates' uses of social media sites and the impact of demographic factors on this. And knowing their objectives and reasons of using social networks. As well as the extent to which the members of the search sample relied on social media as source of information on terrorism issues.

The study concluded many results, including: the rate of use of social networking sites by Egyptian expatriates is very high, perhaps due to the rapid spread and ease of use without complications. The results confirmed that the use of social media sites affects the cognitive, emotional and behavioral fields of the members of the sample, and the effects in all areas were largely represented, with averages of between 203 and 292, and by a percentage of between $46.3 \%$ and $94.2 \%$.

The study (Kafi, Mohammed Abdul Wahab al-Faqih, Salhi, Hatem Ali Haider) [8] focused on knowing the information sought by Arab youth from social networks on the phenomenon of terrorism. In addition to monitoring the factors affecting the Arab youth seeking news and information from social networks on the phenomenon of terrorism. As well as knowing the impact of the dependence of Arab youth on social networks in obtaining news and information about the phenomenon of terrorism.

The study concludes with several findings: Individuals seek primarily to seek specific information and details about terrorist cases and incidents that occur in their countries rather than seeking general information about terrorism. The rate of dependence on the impact of the media raises during crises and transformations experienced by societies.

The objective of the study (Hassan Al-Mutairi, 2012) [9]: is to reveal the nature of the political uses of Twitter and its different purposes and contents on the part of the Kuwaiti youth. The researcher used the descriptive survey method in the study and the questionnaire tool that was applied to a sample of 404 respondents selected in a simple random manner from a variety of young people.

The study has reached many results, the most important of which are: The diverse uses of Twitter that relate to the nature of the work or the function of user ranked first. Next come the uses related to new friendships of both sexes, then the use for entertainment, and in the end the applications of leisure.

The study (Hosni Awad, 2012): examined the impact of social networking sites on the development of youth social responsibility, through the application of a training program to a group of young people (Allar Youth Council) 
in Palestine. The researcher indicated, through the application of the social responsibility scale, respondents who had been trained to create multiple web pages for each respondent group after being exposed to several social responsibility conferences and dialogues.

The study yielded many results, among which: The perception of the sample regarding the concepts and details of social responsibility has changed significantly after the creation of pages on Facebook and their interaction with them.

The study of (Mubarak Zoudeh, 2011) [10] sought to identify the role played by social media in shaping Tunisian public opinion, and the role played by these means in the virtual mobilization of Tunisian public opinion and production of the Tunisian revolution. The study also sought to know the habits and patterns of users of social media sites, and the impact of their use.

The most important results of the study are: Facebook is the most used by the respondents at $79.68 \%$, while daily navigation on social networking sites is the most used attribute of respondents $(71,87 \%)$.

The study of (Hatem Alawneh, 2011) [11] focused on: Identify the nature of the role played by social networking sites, in motivating Jordanian citizens to participate in the mass movement demanding political, economic and social reform through Jordanian trade unionists, using the method of media survey in both descriptive and analytical.

Among the most important results of the study: Social media has played a moderate role in motivating trade unionists to participate in the mass movement, and $19.9 \%$ of trade unionists participate in the mass movement through social networking sites permanently.

The study of (Nasr al-Din al-Adi, 2011) [12] tried to reveal the compatibility and difference in the use of the Internet based on the assumption that the possession of technology does not necessarily unify the use and standardization, and to know the new forms of communication for young people through their use of the Internet. The study used the descriptive survey method based on the questionnaire.

Among the findings of the study is that youth use of the Internet in the UAE varies according to variables such as gender and age, and that its use has led to a strengthening of social relations.

The study of (Taher Abu Zeid, 2011) [13] seeks to identify the impact of social sites on public opinion and explain their implications for political participation through their impact on public opinion, The study relied on proving its hypothesis on the descriptive and analytical methodology based on the questionnaire and interview tool as one of the social survey tools.

One of the most important findings of the study is: Interactive social sites contribute significantly to the influence of public opinion in the Palestinian society.

The study of (Fayez al-Shehri, 2014) [14] focused on extremism and cyber terrorism and revealed that the extremist sites ranging from 240 to 300 websites, as increasing and decreasing according to the hottest events in the Arab and international arena.

The study pointed out that Arab and Western statistics on the number of extremist sites are for the most part characterized by exaggeration and lack of methodology, as some consider all those who seek jihad are extremists, while other researchers see that every site calling for expulsion and resistance against colonialism is part of extremism, even if the nature of the conflict is popular or national or moderate Islamist.

\subsection{WHAT DISTINGUISHES OUR STUDY FROM PREVIOUS STUDIES?}

After a brief review of many studies, perhaps the most striking features of our study compared by previous studies are:

1) Its focus on employing social media websites to promote terrorism issues.

2) Demonstrates the extent to which terrorists use social media to promote their ideas and beliefs.

3) Implemented during the period of intensification of the violence experienced especially by the Arab region, during 2017.

4) Previous studies have focused on linking the study of social networking sites to other issues different from those identified in our study, such as the study of (Reda Abdel-Wajid, 2015) or the study of (Faten AbdelRahman, 2015). 
5) We hope that this study will provide a valuable scientific contribution to previous scientific efforts to use the potential of social networking sites to raise awareness and counter the dangers of deviant and extremist thinking by terrorist groups.

\section{USE OF SOCIAL NETWORK SITES IN THE PROMOTION OF TERRORISM}

\subsection{CHARACTERISTICS OF COMMUNICATION THROUGH SOCIAL NETWORKING}

Internet has gained a great international reputation, and a broad propagation capacity in a much shorter time than other means of communication. The Radio has remained more than 38 years to reach nearly 50 million listeners worldwide, and the TV took 13 years to reach the same number, while the Internet reached that number in four years. The number of Facebook users is estimated at 1.4 billion and $47 \%$ of its users have a presence on social sites [15] Given the rapid and continuous growth in the number of users, the objectives and the diversity of uses have varied.

Previous scientific studies indicated that social networking sites are the most reliable way for the public as a source of information related to terrorism issues, it has grown relative to traditional media such as newspapers, radio and television. This reflects the importance of information sources promoted by social networking sites in tracking events and terrorist issues used by the public because of its rapid spread to follow the news and a continuous and rapid update of what it publishes. [16]

The concept of social networking sites, and public interactive applications running through the Internet, such as online news sites, and broadcasting applications such as Podcast, YouTube, forums, discussion groups, the use of search engines, Facebook and Twitter, as well as website groups. These sites combine the functionality of personal and mass communication, personal media, and allow the user to control the form, quality, content and timing of the communication in which he wishes to participate [17]. The characteristics of social networking sites may be limited to the following: [18] Interpersonal Communication Media: It combines the properties of personal communication and mass communication. This includes E-mail, which features both public and private communication, and Mobil

1) Information Search Media: It is both a source of information and knowledge and an easy and quick access to these resources.

2) Collective Participatory Medium: Group sharing has evolved with the advent of the second generation of Web 2.0, Social Networks, and Social Media, it allows any user to be a publisher who sends his message to others.

3) Interactive Play Medium: Interactive means of communication. Virtual Reality is an interactive feature that provides interactivity to users and aims to take advantage of sharing and performance rather than Content in Ratification. The sender and the receiver exchange their roles, the communication is bidirectional and reciprocal, and not unilateral, it is a dialogue between two parties. This interactive feature is exploited in the process of persuasion.

4) Substitution: replacement of other means. The user can browse printed and electronic newspapers, track radio and TV stations, offer audio programs and download sound, and view movies and videos, including the popular YouTube, to participate in videos.

It is clear that social networking sites combine a number of means and functions in a comprehensive manner and that their features are not distinct from the role of traditional media but have many complementary features.

Connecting via social networking sites has many features, including: [19]

1) Asynchronous: Enables quick interaction with the communication process for the individual, whether he is emitter or sender.

2) Movement and flexibility: modern means can be transferred to the recipient or sender, such as laptops, mobile phones and other devices, to take advantage of them.

3) Media integration: Use multiple communication methods, such as text, sound, still image, animation, 2D and 3D graphs, etc. 
4) Attention and focus: The user of the sites is active in the selection and interaction with the content and this is characterized by a high degree of attention and concentration.

5) Storage and preservation: It is easy for the user to store, save and retrieve communication messages as part of the capabilities and features of the device itself.

According to the researchers, "Levero and Livingstone," the communication through social networking sites, is characterized by the following: [20]

1) Interconnectedness: It allows the communication of several points to several other points, not only from a single point to several points.

2) Easy access: From users who operate as senders, recipients and producers.

3) Diversity of content: In terms of political, social and cultural media content, news, information, films, series and various other fields.

4) Open-ended: Versatility and openness to novelty in terms of the content of the information media.

McWill has identified the social networking domains that affect the target audience as follows: [21]

The power of influence: It is highly capable of influencing users.

1) Social change and development: Through its power of influence over social change, because of its appeal to the public and its interactive properties, and the public used to interact with them voluntarily or willingly.

2) Transcend the challenges of space and time: Social media have been freed from space and time restrictions and messages sent to sites come from anywhere in the world and reach the world very quickly and in many ways, including news and information, as well as chat rooms. And the spread and freedom of space "Delocatedness". Which made it not related to a specific geographical area.

3) Social sites allow their users to create private pages and spaces within the site itself, then connect and communicate with other users and share content. [22] That's why terrorists use it to send their ideas and influence their followers on Facebook, YouTube, Twitter and other sites.

\subsection{EXPLOITING SOCIAL MEDIA TO PROMOTE TERRORISM ISSUES}

The concept of "terrorism" came from the Latin origins Terroris, and Terror means fear. [23] Despite the many definitions of terrorism, some forces and international organizations are trying to define and interpret it from their point of view and in the service of their goals and interests. According to the Arab Convention for the Suppression of Terrorism in 1998, terrorism is any act or threat of violence of any nature or purpose that is committed during the implementation of an individual or group criminal project, it aims to terrorize or frighten people by endangering their lives, freedom or safety. Or put in danger public or private facilities and assets or occupy it or seize it or endanger any national resource. [24]

Arabic encyclopedias and dictionaries define "terrorism" as a word derived from the act of "terrorized". An act of the same substance which is "horrify" - رهب - means fear and consternation. Journal of Islamic Research. 2012 " (Taha, 2015, p. 6) [25] \& (Al-Ani, 2013, p. 79)

Robert's dictionary defined terrorism as the systematic use of means that use violence to achieve a political objective [26].

There is no agreement to define a specific concept of terrorism for reasons dictated by ideological political and intellectual conditions of the prevailing regimes in contemporary societies (Al-Dulaimi, 2010, p. 180). [27]

Although some peoples belonging to a particular culture and country consider an act as terrorism may be this same act is considered by others as heroism, courage, resistance and liberation, so this problem has contributed to confusion, overlap and chaos in presentation, processing and analysis. (Kirat 2014, 10). [28] The definition of terrorism has multiplied and bifurcated to the extent of divergence, as example: Terrorism is a special type of tyranny which is not bound by law and rules and does not pay attention to its victims and directed strikes that doesn't take a specific pattern towards its intended objectives in order to create an atmosphere of terror and fear and paralyze the effectiveness of victims (Al-Dulaimi, 2002 , P. 80). [29]

In this study, we adopt the definition of the Arab Observatory of Extremism and Terrorism, as we have noted its clarity, conciseness and comprehensiveness. It refers to terrorism as "any act aimed at terrorizing an individual, 
group or state in order to achieve objectives and interests that are not permitted by domestic or international laws" (Arab Observatory.com - 2014). [30]

So, Social Networks allow users to create pages and private spaces within the same site, and then use them to connect, communicate and share content with other users. [31]This characteristic allowed terrorist groups to employ them in many areas to serve their interests, most notably:

1) Propaganda: This is one of the main functions of social networking sites by terrorist groups, and this propaganda is in form of texts, images and videos that explain their goals and ideas.

2) Recruitment: Terrorist groups use social networking sites to build relationships and seek support from sympathetic audiences, as well as private chats.

One of the media features of social networking sites is the speed of transmitting events with images rather than words, like what YouTube does, and the media function has gone from promoting words to promoting images. This function has made social networking sites the best, safest, and fastest-spread option for terrorist groups, through which they enter society and intensify their promotion and recruitment efforts to achieve their goals. Deal with its problems and effects and demonstrate it by accessing social networking sites. On the other hand, individuals and organizations are striving to combat terrorism, and the intensification of conflict has become evident between those who promote terrorism and those who deal with its problems and effects, that is what the access to social networking sites shows.

Social networking sites promoting terrorism cases range from 240 to 300 websites and increase or decrease according to the hottest events in the Arab and international arena. Most are exaggerated and lack methodology, as some consider all jihadists to be extremists, while others believe that all sites of expulsion and resistance are part of extremism, whatever the nature of the presentation: 'National Islamist, popular or moderate. Over the last ten years, virtual entities have been created as media centers or institutions whose creation costs only an attractive advertisement that leads the Internet browser to a site created by its owner to rebroadcast and to promote content and fatwas evoking extremism. Emphasizing that cyber-extremism groups are characterized by great vitality in dissemination, disguise and appearance.

Extremist groups not only send emails but have penetrated the sites of forums far from suspicion, such as sports sites, women, sexuality and young audiences, to exchange information and images targeted sites. [32] There are serious electronic issues in the prevalence of the phenomenon of electronic fatwas passed through social networking sites since 2001, we must warn about the degree of danger of the content of these sites and forums, which contain electronic dialogues, false news and misleading rumors and abuse of religion, beliefs, and Islamic decisions.

The technological development of the use of social media sites has provided an unexpected service to the terrorist organizations that exploit them to carry out their operations against the security of peoples and communities, as well as their criminal acts aimed at state infrastructure, and provided simple and multiple methods for transferring ideas, data and information to terrorist groups in the absence of security services at first, it has managed to draw a crowd of young people into the clutches of terrorist groups to implement terrorist practices. These sites also generated an unlimited flow of information and data to these organizations, that to use them in recruiting terrorists to conduct terrorist operations. [33]

The use of social networking sites by terrorist groups is also being used to reach out to some young people, and their petitions under various justifications to carry out criminal operations or terrorist acts, which are promoted and instilled in the hearts and minds of reckless young people, especially those in need of money. We quote as an example the Egyptian university student, who was planning a terrorist attack on one of the densely populated markets of Maadi, which withdrew, in October 2017, from his crime at the last minute to present with his car loaded with 10 kilograms of explosives at a police station. The young man admitted in the investigation that he had received misleading information through social media to carry out a criminal operation against residents in the Maadi neighborhood. [34] As well as the live and direct broadcast of the burning of the Jordanian pilot by the ISIS groups in Iraq, through social networking sites.

Some social networking sites promote destructive ideas, through the content conveyed and promoted in the minds of young Arabs, including the appearance of "Satan-worshipers"* incidents, which provoked feelings of anger and resentment in the Egyptian and Arabic streets about the danger of these sites on young Muslims and the denial of their faith. [35] Terrorists use social networking sites because of their ability to communicate with others, especially those in the youth category, to spread their ideas thoughtfully to convince these young people of extremist 
thinking, whether through religion or by their principles or by violent ideas. These risks can be reduced as much as possible by monitoring what is displayed on social media sites, by not receiving the broadcast of a specific entity or center, and by blocking negative information, by constantly monitoring various sources promotion, in order to identify what represents the source of the risks and by applying a method of blocking, especially since there are devices and programs that ensure the monitoring of the communication network and the tracking of messages exchanged. These procedures are currently being followed by the United States of America in the navigation and tracking of sites that doubt content. In our field study, we seek to identify the point of view of a sample of users of social networking sites on the phenomenon of terrorism.

\section{ANALYSIS OF THE FIELD STUDY RESULTS}

\subsection{ANALYSIS OF RESPONDENTS' PERSONAL DATA}

Table 1: shows the sample distribution of the study by gender

\begin{tabular}{|l|l|}
\hline Gender & Percentage $\%$ \\
\hline Male & $73.4 \%$ \\
\hline Female & $26.6 \%$ \\
\hline TOTAL & $100 \%$ \\
\hline
\end{tabular}

The results in Table (1) indicate that the majority of the study sample was male at $74.4 \%$, while the percentage of women was $26.6 \%$, indicating the low percentage of women using social networks, especially in Yemen, although the percentages in Tunisia are close, the researchers wanted to reach a larger number of women so that the ratio is close to the number male, but it was the best choice possible. This is for two reasons: first, the absence of Yamani women who use social networks in the research audience. The second is the difficulty of communicating with the Yamen women's group: as a conservative society, the researchers were not able to communicate directly with them because they had more access to Male.

Table 2: shows the distribution of the study sample by age

\begin{tabular}{|l|l|}
\hline Age group & Percentage $\%$ \\
\hline From 18 to less than 35 years & $46.7 \%$ \\
\hline From 35 to less than 45 years & $48.1 \%$ \\
\hline From 45 to less than 55 years & $4.4 \%$ \\
\hline More than 55 years & $0.7 \%$ \\
\hline TOTAL & $100 \%$ \\
\hline
\end{tabular}

The results in Table 2 indicate that most of the study sample was in the 36 to 45 age group (48\%), followed by the 18 to 35 age group (47\%). This is normal because both stages are the most active phase in the use and tracking of social networking site posts.

Table 3: shows the educational qualifications of the study sample

\begin{tabular}{|l|l|}
\hline Qualifications of the study sample & Percentage \% \\
\hline High School & $13.3 \%$ \\
\hline Higher Diploma & $3 \%$ \\
\hline Bachelor's degree & $42.2 \%$ \\
\hline Higher studies (Masters and Ph.D.) & $41.5 \%$ \\
\hline TOTAL & $100 \%$ \\
\hline
\end{tabular}

The results in Table (3) indicate that most respondents in the study sample had a university level of $42 \%$, followed by Higher studies graduates with $41 \%$, followed by high school with $13 \%$ and the percentage those with a higher degree only 3\%. This means that the highest percentage of the sample in the study are educated and at an advanced stage of education, and we can count on their answers, in the sense that they are able to understand the 
use the social networking sites, and therefore to answer the paragraphs of the questionnaire in a rudimentary and objective way.

Table 4: shows the distribution of the study sample according to marital status

\begin{tabular}{|l|l|}
\hline Marital status of the study sample & Percentage \% \\
\hline Single & $18.2 \%$ \\
\hline Married & $81.8 \%$ \\
\hline Divorcee & $0 \%$ \\
\hline Separated & $0 \%$ \\
\hline TOTAL & \\
\hline
\end{tabular}

The results in Table (4) indicate that most respondents in the study sample are married (81.8\%) while single people are (18.2\%). This result goes well with the sample of the study and gives a clear indicator that the respondents live in family and emotional stability, that means they will not be affected by the claims of groups that promote terrorism.

Table 5: shows the average of monthly expenditure of the study sample

\begin{tabular}{|l|l|}
\hline Monthly Spending Rate & Percentage $\%$ \\
\hline Less than \$ 500 & $41.4 \%$ \\
\hline From \$ 500 to less than \$ 1000 & $24.8 \%$ \\
\hline From \$ 1000 to \$ 3000 & $24.8 \%$ \\
\hline More than \$ 3000 & $9 \%$ \\
\hline TOTAL & $100 \%$ \\
\hline
\end{tabular}

The results of Table (5) indicate that the level of monthly expenditure of the public sample varies, as the highest percentage spends less than $\$ 500$ per month, which means low income level for the largest number of the study sample. Such economic situation can affect any individual in any society.

Table 6: shows the work area of the study sample

\begin{tabular}{|l|l|}
\hline Area of employment & Percentage $\%$ \\
\hline Governmental & $45.9 \%$ \\
\hline Private & $32.6 \%$ \\
\hline Mixed (Semi-state) & $7.4 \%$ \\
\hline Unemployed & $14.1 \%$ \\
\hline TOTAL & $100 \%$ \\
\hline
\end{tabular}

The results in Table (6) indicate that most of the study sample works in public organizations, where the percentage reaches $46 \%$, and $33 \%$ of respondents work in the private sector, while $14 \%$ are unemployed and do not have a job. This percentage may be the most users of social networking sites. They can be easily influenced on the pretext of providing a job.

Table 7: shows the political and party affiliation of the study sample

\begin{tabular}{|l|l|}
\hline Political and party affiliation & Percentage \% \\
\hline Belongs to a political party & $69.2 \%$ \\
\hline Independent & $30.8 \%$ \\
\hline TOTAL & $100 \%$ \\
\hline
\end{tabular}

The results in the table (7) indicate that most of the study sample belongs to parties or political organizations, with $69.2 \%$, while $30.8 \%$ of respondents reported being independent. This result is expected given the political climate in Yemen and Tunisia, as well as the fact that they can use social media to express their views and intellectual trends. 
Table 8: shows the duration of use of the study sample for social networking sites during the day.

\begin{tabular}{|l|l|}
\hline Duration of use & Percentage \% \\
\hline Less than an hour & $5.8 \%$ \\
\hline From an hour to less than two hours & $27.7 \%$ \\
\hline From two hours to less than three hours & $32.1 \%$ \\
\hline From three hours to less than four hours & $16.1 \%$ \\
\hline Four hours or more & $18.2 \%$ \\
\hline TOTAL & $100 \%$ \\
\hline
\end{tabular}

The results in the table (8) indicate that most respondents in the sample use their social media sites for at least an hour a day, where $32 \%$ of the sample uses three hours daily and $18 \%$ exceeds their daily use four hours. The results confirm that the sample members are activists and use social media sites frequently.

Table 9: shows the order of the most used social media sites by the study sample

\begin{tabular}{|l|l|}
\hline Name of the site & Percentage $\%$ \\
\hline WhatsApp & $83.6 \%$ \\
\hline Facebook & $68.7 \%$ \\
\hline You Tube & $24.6 \%$ \\
\hline Tweeter & $22.4 \%$ \\
\hline Instagram & $14.9 \%$ \\
\hline Telegram & $13.4 \%$ \\
\hline Snapchat & $6.7 \%$ \\
\hline Other Sites & $2.2 \%$ \\
\hline TOTAL & $100 \%$ \\
\hline
\end{tabular}

\section{Figure 1 shows the range of social media sites}

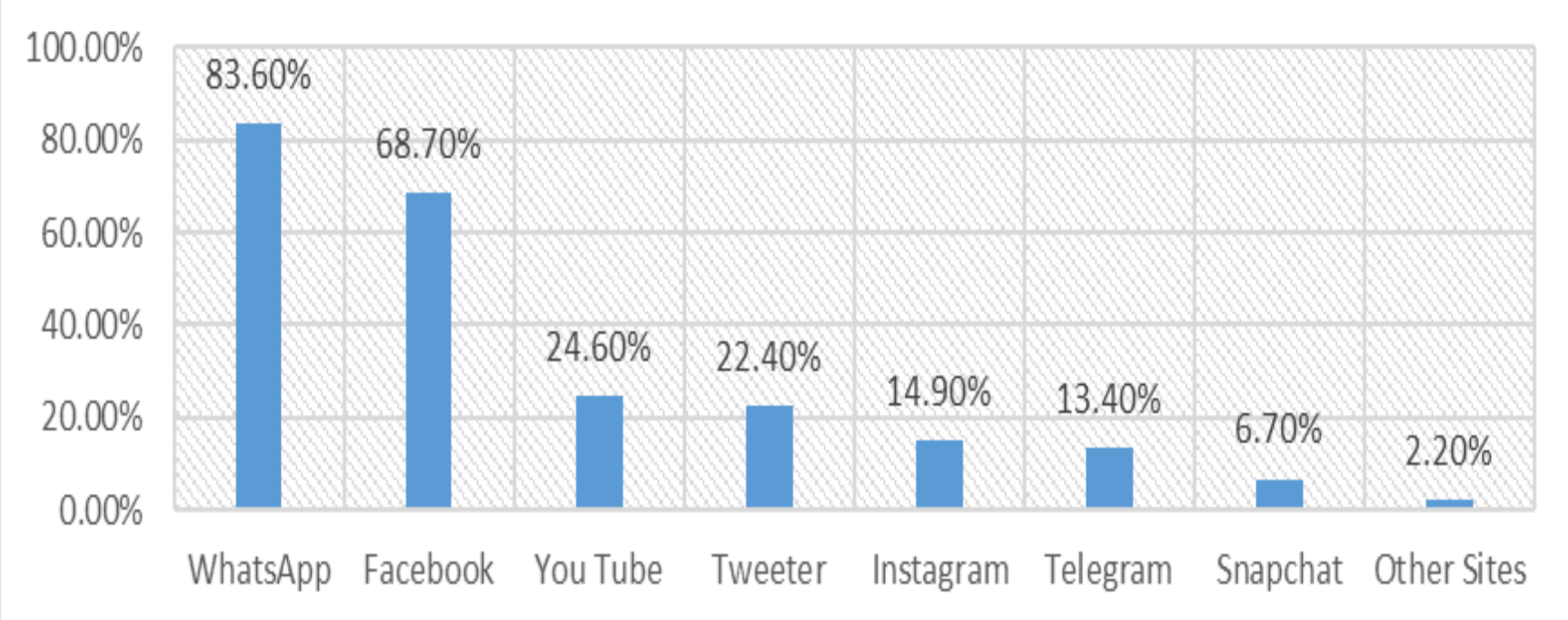

The results in Table (9) and Chart (1) indicate that most of the study sample makes extensive use of social networking sites, WhatsApp was ranked first in terms of usage with 84\%, followed by Facebook with 69\%, YouTube with $24 \%$, Twitter with $22 \%$, Instagram by $14 \%$, Telegram by $13 \%$, Snapchat by $6 \%$ and $2 \%$ were distributed among other social networking sites such as LinkedIn, blogs and other sites. 


\subsection{SOCIAL SITES WHERE TERRORIST GROUPS ARE ACTIVE}

Table 10: Shows the social sites in which terrorist groups are active, from the point of view of the study sample who use social sites

\begin{tabular}{|l|l|}
\hline Name of the site & Percentage $\%$ \\
\hline WhatsApp & $31 \%$ \\
\hline Facebook & $66.4 \%$ \\
\hline You Tube & $37.2 \%$ \\
\hline Tweeter & $40.7 \%$ \\
\hline Instagram & $8 \%$ \\
\hline Telegram & $16.8 \%$ \\
\hline Snapchat & $7.1 \%$ \\
\hline Other Sites & $18.6 \%$ \\
\hline TOTAL & $100 \%$ \\
\hline
\end{tabular}

\section{Figure 2 shows the sites where terrorist groups operate}

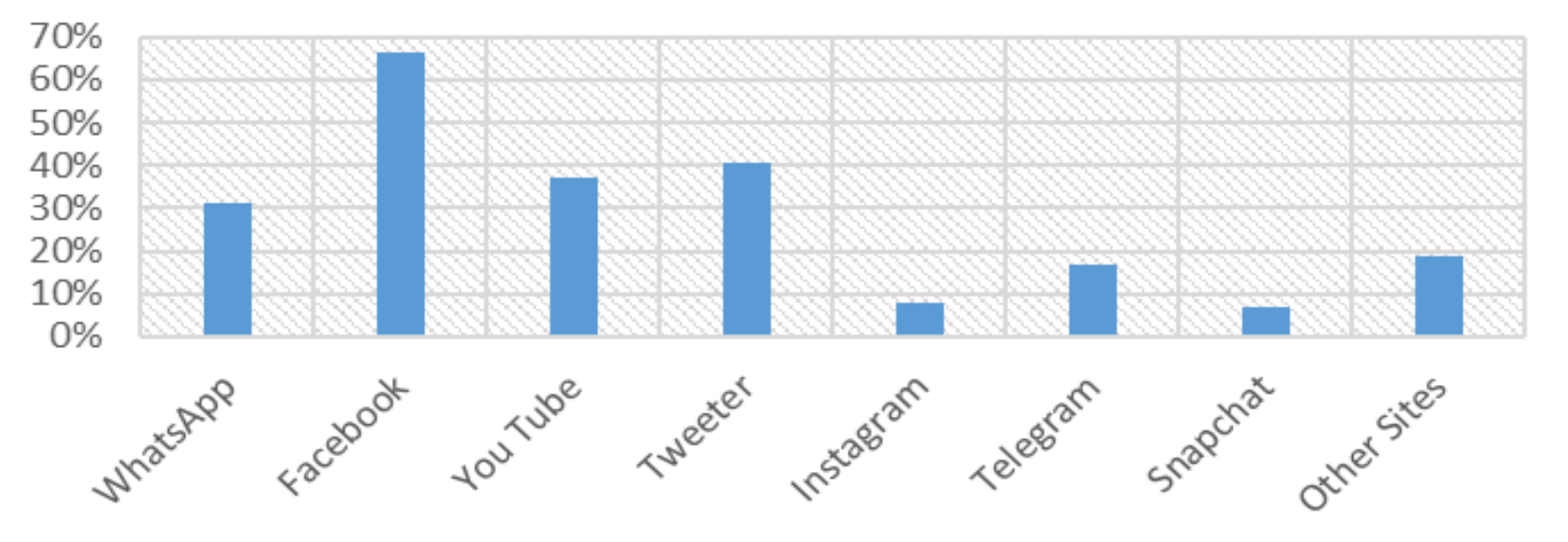

The results of Table (10) and Figure (2) indicate that most respondents believe that Facebook is the most used site by terrorist groups, with 66\%. Followed by Twitter (41\%), YouTube (37\%), WhatsApp (31\%), Telegram (16\%), Instagram (8\%), and 18\% among other social media sites. Such as LinkedIn, blogs, private sites, personal pages, etc. This can be a logical result for a number of reasons, firstly because Facebook is one of the first social sites that appear on the Internet, and secondly, the results of previous studies have shown that this site was one of the most important social sites used in many Arab countries and in the world.

\subsection{TERRORISM ISSUES AS A PRIORITY FOR SOCIAL MEDIA}

\begin{tabular}{|l|l|}
\hline & Terrorism issues are a priority for social media \\
\hline Agree & $24 \%$ \\
\hline Partly & $52 \%$ \\
\hline Disagree & $24 \%$ \\
\hline
\end{tabular}




\section{FIGURE 3: TERRORISM ISSUES ARE A PRIORITY FOR SOCIAL MEDIA}

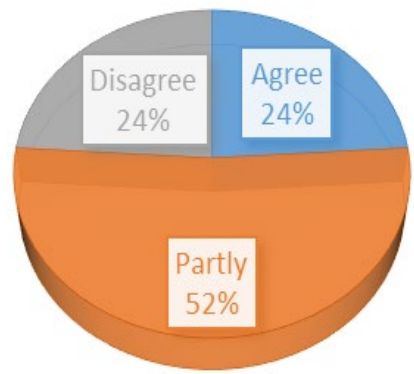

The results of Figure (3) indicate that $52 \%$ of respondents believe to some extent that the issues of terrorism are some of the priorities of social networking sites. While $24 \%$ agreed that terrorism is a priority for social media, and the same percentage did not agree that terrorism issues are a priority for social media. This means that terrorism issues are spreading through websites and can affect users broadly. The countries of the world in general and the Arab and Islamic countries in particular are suffering from the events of terrorism, which become the focus of social media users' attention, making it a priority for the media functions of social networking sites, as confirmed by more than half of the respondents.

\subsection{OBJECTIVE ENGAGEMENT OF SOCIAL MEDIA SITES IN THEIR COVERAGE OF TERRORISM ISSUES}

\begin{tabular}{|l|l|}
\hline & Social media websites are positively engaged in their coverage of terrorism issues \\
\hline Agree & $11 \%$ \\
\hline Partly & $45 \%$ \\
\hline Disagree & $44 \%$ \\
\hline
\end{tabular}

FIGURE 4: SOCIAL MEDIA WEBSITES ARE POSITIVELY

ENGAGED IN THEIR COVERAGE OF TERRORISM

ISSUES

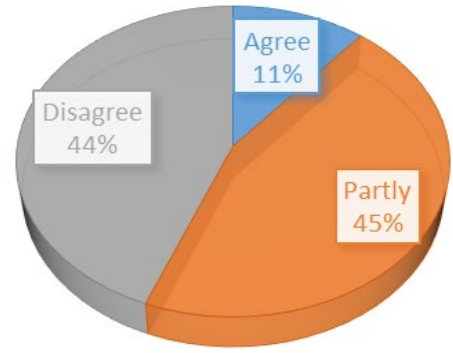

Figure (4) shows that only $11 \%$ of respondents agree that social media sites are objective in their coverage of terrorist cases, while $44 \%$ of respondents disagree with this view, while $45 \%$ of respondents agree to some extent that the sites are committed objectively in their coverage of terrorism.

\subsection{SOCIAL NETWORKING SITES CONVEY THE TRUTH IMPARTIALLY}

\begin{tabular}{|l|l|}
\hline & Social networking sites convey the truth abstractly as it is: \\
\hline Agree & $9 \%$ \\
\hline Partly & $31 \%$ \\
\hline Disagree & $60 \%$ \\
\hline
\end{tabular}




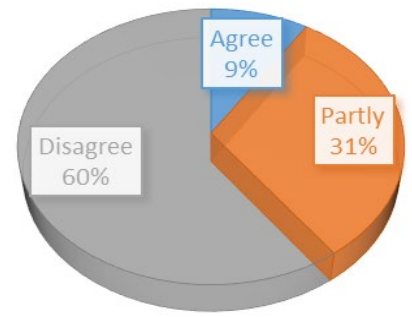

Figure (5) shows that $60 \%$ of respondents do not agree that social networking sites convey the truth impartially. This percentage represents the opinion of more than half of the study sample, while only $9 \%$ of respondents agreed that social networking sites convey the truth as it is. This approach gives a clear indication of the manipulation of information posted by social sites and could be exploited by terrorist groups.

\subsection{THE CLASSIFICATION OF TERRORISM CASES IS SUBJECT TO THE TENDENCIES AND BELIEFS OF THOSE WHO MANAGE AND SUPERVISE THE SOCIAL NETWORKING SITE}

\begin{tabular}{|l|l|}
\hline & $\begin{array}{l}\text { The classification of terrorism cases is subject to the tendencies and beliefs of those who manage and } \\
\text { supervise the social networking site }\end{array}$ \\
\hline Agree & $54 \%$ \\
\hline Partly & $35 \%$ \\
\hline Disagree & $11 \%$ \\
\hline
\end{tabular}

FIGURE 6: THE CLASSIFICATION OF TERRORISM CASES IS SUBJECT

TO THE TENDENCIES AND BELIEFS OF THOSE WHO MANAGE AND SUPERVISE THE SOCIAL NETWORKING SITE

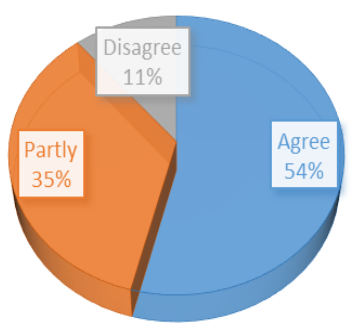

The results in Figure (6) indicate that this result is an explanation of its predecessors, more than half of respondents believe that personal attitudes and convictions affect social media activists and users in classifying terrorism cases, this is one of the most important challenges in terms of objectivity and impartiality, which confirms the findings of previous studies that objectivity in its absolute is not possible for many reasons, including personal tendencies and the most important beliefs.

\subsection{HAVE TERRORISM ISSUES BEEN APPROVED ON SOCIAL MEDIA?}

\begin{tabular}{|l|l|}
\hline & Terrorism issues have been approved on social media \\
\hline Agree & $54 \%$ \\
\hline Partly & $35 \%$ \\
\hline Disagree & $11 \%$ \\
\hline
\end{tabular}




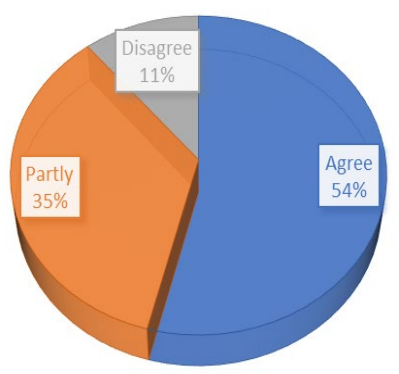

The results in Figure (7) indicate a difference in the opinion of the sample on terrorism issues, due to the difference of opinion on the definition of the concept of terrorism. Often, there is disagreement on the interpretation of national terrorism cases, due to the entrenchment of one party against another, for example, in the current Yemeni situation, there are two parties, each accusing the other of terrorism and sees himself innocent, this is clearly shown by following party reports on social networking sites.

\subsection{SOCIAL NETWORKING SITES CONTRIBUTE TO DISTORTING FACTS}

\begin{tabular}{|l|l|}
\hline & Social media contribute to distorting facts and do not describe reality as it is. \\
\hline Agree & $48 \%$ \\
\hline Partly & $42 \%$ \\
\hline Disagree & $10 \%$ \\
\hline
\end{tabular}

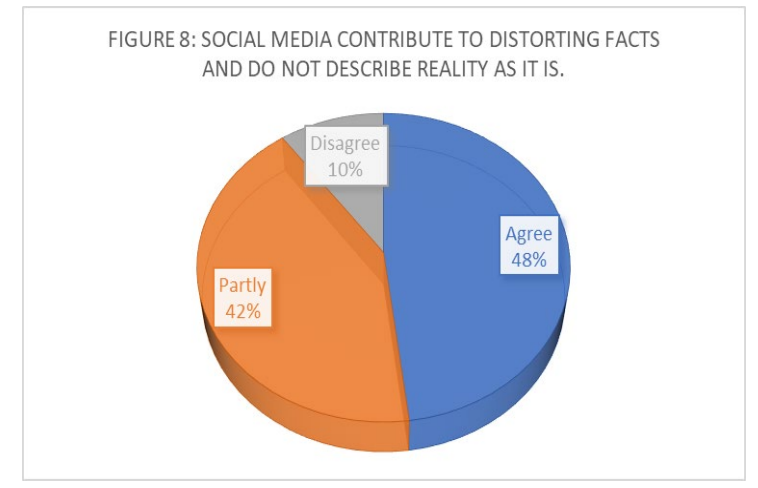

The results of Figure 8 show that when a terrorist case is committed by a specific group or entity, and then social media appear to justify it and place it outside the circle of terrorism, it contributes to distort the facts and does not describe the reality as it is. This is what the sample members agree on.

\subsection{SOCIAL MEDIA PROVIDERS HAVE LIMITS TO WHICH THEY ARE COMMITTED}

\begin{tabular}{|l|l|}
\hline & Social media providers have limits to which they are committed. \\
\hline Agree & $26 \%$ \\
\hline Partly & $49 \%$ \\
\hline Disagree & $25 \%$ \\
\hline
\end{tabular}




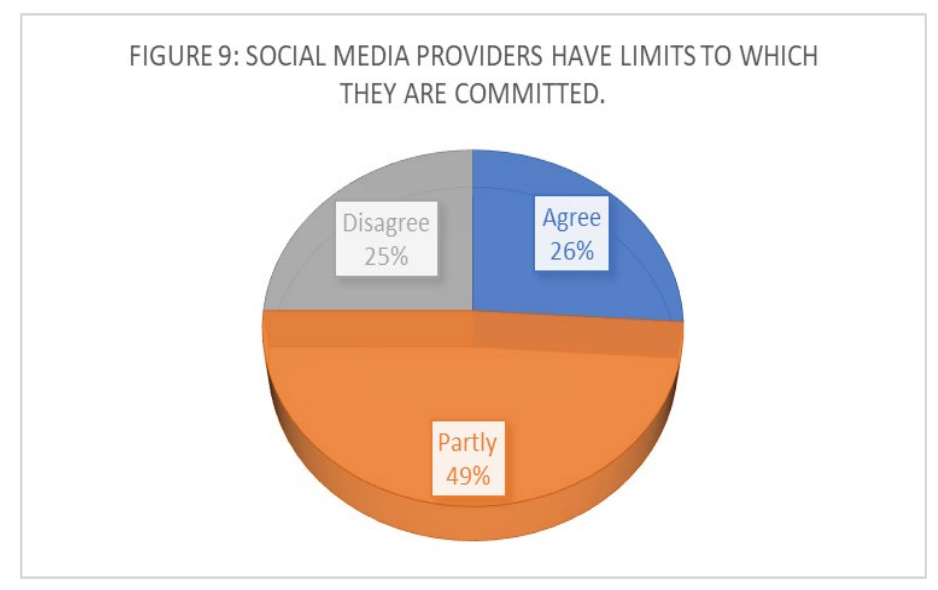

The results in Figure (9) indicate that over half of those surveyed believe that people who manage social media sites respect limits while covering terrorism cases.

\subsection{SOCIAL MEDIA INTEREST IN TERRORISM ISSUES BECAUSE THEY ARE INTERESTING AND DRAW ATTENTION}

\begin{tabular}{|l|l|}
\hline & Social media interest in terrorism issues because they are interesting and draw attention. \\
\hline Agree & $40 \%$ \\
\hline Partly & $50 \%$ \\
\hline Disagree & $10 \%$ \\
\hline
\end{tabular}

FIGURE 10: SOCIAL MEDIA INTEREST IN TERRORISM ISSUES

BECAUSE THEY ARE INTERESTING AND DRAW ATTENTION:

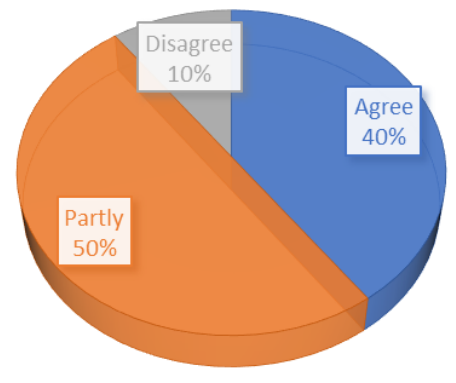

The results in Figure (10) indicate that terrorism-related issues are the most interesting and popular ones, and thus attract the most attention from social networking sites, social media accounts need more audiences, subscribers and users who are attracted to terrorism issues, which has been approved by most of the sample. In this respect, terrorist groups find an entry to broadcast their material and bring their followers, their public and their followers. Proponents of propaganda and admirers disseminate these materials, consciously or not, to achieve the goals of terrorist groups.

\subsection{THERE IS A DIVERGENCE ON TERRORISM ISSUES FOR SOCIAL MEDIA}

\begin{tabular}{|l|l|}
\hline & There is a divergence on the issues of terrorism from the social media point of view. \\
\hline Agree & $42 \%$ \\
\hline Partly & $48 \%$ \\
\hline Disagree & $10 \%$ \\
\hline
\end{tabular}




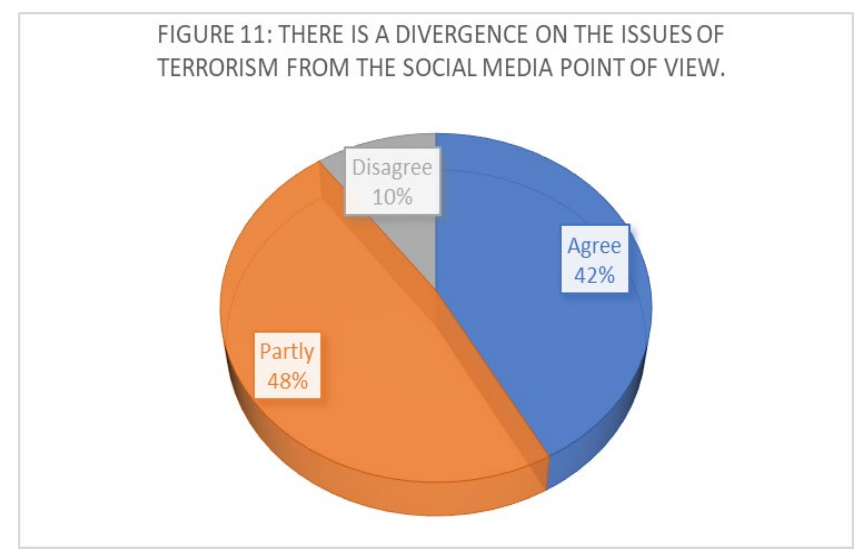

The results in Figure (11) indicate that more than half of the study's sample believes there is a discrepancy in the content of media documents posted on social media sites dealing with terrorist issues. This is due mainly to the lack of agreement on a common definition of terrorism, as well as the intellectual and cultural background, trends and convictions among social media users.

\subsection{THE MATERIAL POSTED ON SOCIAL MEDIA ACCOUNTS IS AFFECTED BY THE SOCIAL SITE POLICY}

\begin{tabular}{|l|l|}
\hline & $\begin{array}{l}\text { Media materials published on social media accounts are influenced by the policy of the media } \\
\text { organization to which they belong. }\end{array}$ \\
\hline Agree & $71 \%$ \\
\hline Partly & $25 \%$ \\
\hline Disagree & $4 \%$ \\
\hline
\end{tabular}

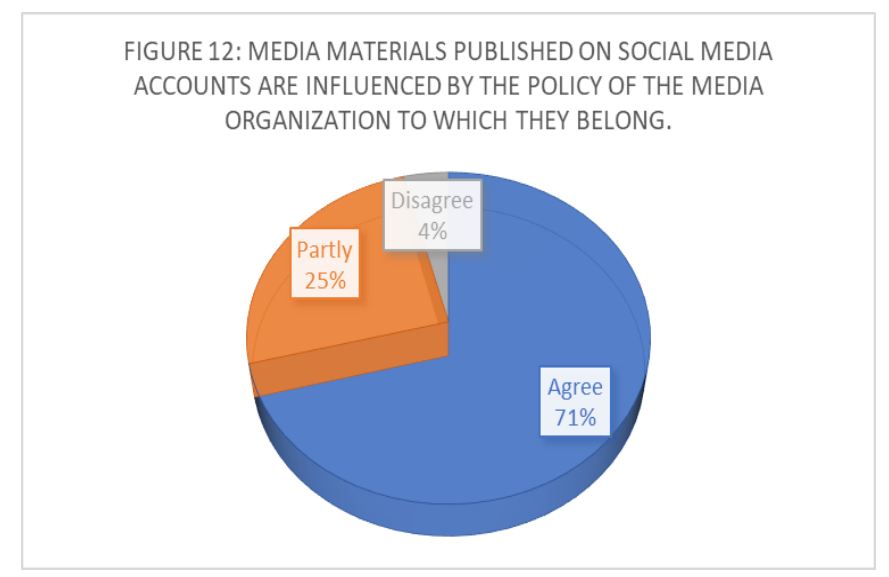

The results of Figure (12) indicate that the policy of media organizations is one of the most important factors and pressure on the content of social networking sites, it's a fact that brings together almost everyone's opinion of the sample. This paragraph refers to the site accounts of social media institutions, which are the spokespersons of the groups and their policies and address the problems of terrorism as they see them.

\subsection{THE IMPACT OF THE INTELLECTUAL TREND ON SOCIAL MEDIA COVERAGE OF TERRORIST ISSUES}

\begin{tabular}{|l|l|}
\hline & $\begin{array}{l}\text { Social media sites in their coverage of terrorist issues are influenced by the intellectual direction of the } \\
\text { managers. }\end{array}$ \\
\hline Agree & $68 \%$ \\
\hline Partly & $28 \%$ \\
\hline Disagree & $4 \%$ \\
\hline
\end{tabular}




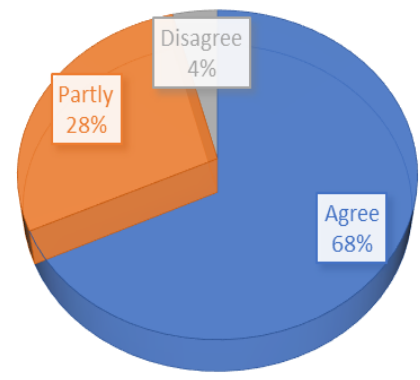

The results of Figure (13) indicate that most of the sample of the study confirms that one of the strongest factors affecting the type of the content published on social networking sites when covering terrorist issues, are the intellectual direction and ideological background of their responsible.

\subsection{IMPACT OF INTERNATIONAL MEDIA CLASSIFICATION ON TERRORISM ISSUES}

\begin{tabular}{|l|l|}
\hline & $\begin{array}{l}\text { The media material on social media sites is influenced by the international media's classification of } \\
\text { terrorism issues }\end{array}$ \\
\hline Agree & $43 \%$ \\
\hline Partly & $53 \%$ \\
\hline Disagree & $4 \%$ \\
\hline
\end{tabular}

FIGURE 14: THE MEDIA MATERIAL ON SOCIAL MEDIA SITES IS

INFLUENCED BY THE INTERNATIONAL MEDIA'S

CLASSIFICATION OF TERRORISM ISSUES.

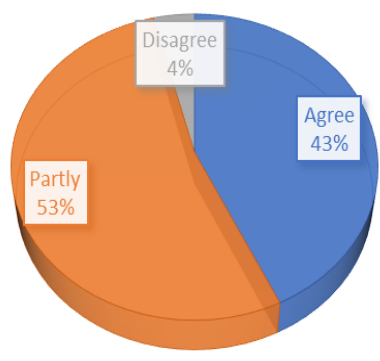

The results of Figure (14) indicate that more than half of the sample confirms that the media materials published through social media sites are affected by the international media classification of terrorism cases. Like the rest of the world, the Arab world is influenced by the policies of the great powers that control international decisions and adhere to them. This is true for media organizations and social media accounts, which often do not exceed them.

\subsection{SOCIAL NETWORKING SITES ARE AN IMPORTANT AND COMPLEMENTARY PART OF TERRORIST OPERATIONS}

\begin{tabular}{|l|l|}
\hline & Social networking sites can be an important and complementary part of any terrorist operation. \\
\hline Agree & $47 \%$ \\
\hline Partly & $45 \%$ \\
\hline Disagree & $8 \%$ \\
\hline
\end{tabular}




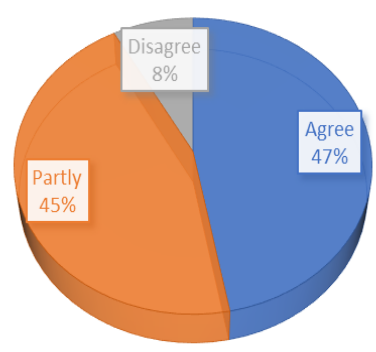

The results of Figure (15) indicate that $47 \%$ of respondents believe that social networking sites play an important, complementary and calculated role for any terrorist operation. It confirms what many studies and specialists have pointed out and explained that any terrorist operation aims to achieve many goals, most notably spreading terror and fear in the community. This has been achieved by social networking sites, where they found a safe place to cover media for all their activities and their work and highlight the violent event, from which the media quoted their news. That's why social networking sites were accused of partnering with terrorists in their operations.

\subsection{TERRORIST GROUPS ARE KEEN TO BENEFIT FROM SOCIAL MEDIA}

\begin{tabular}{|l|l|}
\hline & The terrorist is keen to use social media to spread his ideas and carry out his operations. \\
\hline Agree & $60 \%$ \\
\hline Partly & $33 \%$ \\
\hline Disagree & $7 \%$ \\
\hline
\end{tabular}

FIGURE 16: THE TERRORIST IS KEEN TO USE SOCIAL MEDIA TO

SPREAD HIS IDEAS AND CARRY OUT HIS OPERATIONS.

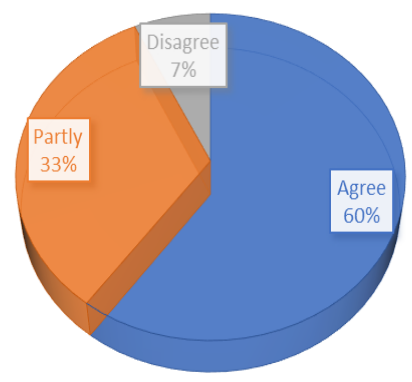

The results of Figure (16) indicate that this paragraph confirms and matches the result of the previous paragraph, the terrorist is keen to take advantage of social networking sites to achieve his goals and disseminate his ideas and confirms the previous accusation of being a partner of terrorists.

\subsection{CONTRIBUTION OF SOCIAL NETWORKING SITES TO THE SPREAD AND POPULARITY OF TERRORIST GROUP OPERATIONS}

\begin{tabular}{|l|l|}
\hline & $\begin{array}{l}\text { Social networking sites contribute to the wide spread of the operations of terrorist groups, gain wide } \\
\text { fame and provide them with opportunities and privileges }\end{array}$ \\
\hline Agree & $58 \%$ \\
\hline Partly & $35 \%$ \\
\hline Disagree & $7 \%$ \\
\hline
\end{tabular}




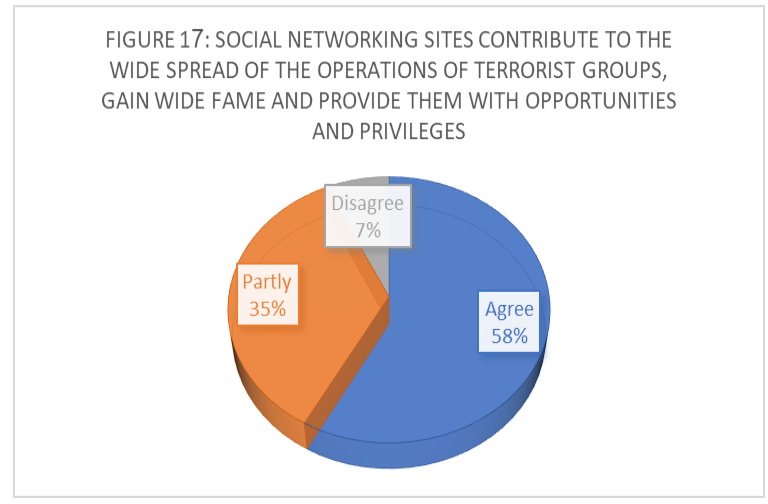

The results of Figure (17) indicate that the views of the respondents are consistent with the previous two paragraphs on the contribution of social media sites to the wide spread of terrorist group operations. Many terrorist operations remain limited in impact and do not exceed their time and geographic framework until they are addressed and communicated by social media.

\section{DISCUSSION OF THE THEORETICAL AND FIELD STUDY RESULTS}

In light of what has been clarified in the theoretical study area, social networking sites have multiple multimedia functions and are characterized by advanced communication features between users, including:

1) Technical development has provided unanticipated service to terrorist organizations and groups and used them to carry out their terrorist operations aimed at protecting the security of individuals and communities.

2) It promotes good and bad media content in the religious, political, cultural, social fields, and other areas. It is a double-edged sword whose potential can be employed in useful or harmful fields.

3) Its distinctive abilities in the power of influence, spread, persuasion and influence have been employed by terrorist groups or organizations to cyber-promote their extremist ideas.

4) The characteristics of cyber-extremism are obvious by using them in propaganda, this is one of its essential functions, especially in recruitment, to create relationships with website users.

5) Terrorist groups are the most widely disseminated, promoted and communicated to users of multiple social sites, highlighted by the actions of ISIS and Al-Qaida, who use sophisticated media techniques to influence.

\subsection{THE FIELD STUDY REACHED SEVERAL RESULTS, WHICH MAY HAVE ACHIEVED ITS OBJECTIVES, INCLUDING}

1) Most of respondents use social networking sites at least one hour per day, with $32 \%$ of the sample using daily less than three hours per day and 18\% exceeding their daily use four hours. These results confirm that the respondents are active in the use of social media.

2) Most of the sample of the study use social networking sites to a high degree, and WhatsApp came first in terms of use by $84 \%$, followed in the ranking of Facebook by $69 \%$, then YouTube by $24 \%$, then Twitter by $22 \%$, and Instagram by $14 \%$, Followed by Telegram by $13 \%$, Snapchat by $6 \%$, and $2 \%$ among other social networking sites, such as LinkedIn and blogs and other sites.

3) Most respondents believe that Facebook is the most widely used by terrorist group with 66\%, followed by Twitter (41\%), YouTube (37\%), WhatsApp (31\%), Telegram (16\%), and Instagram (8\%). 18\%, among other social networking sites, such as LinkedIn, blogs, private sites, personal pages, and other sites.

4) This result can be normal, because it is due to several reasons, including that Facebook is one of the first social sites to appear on the Internet, and secondly, many of the results of previous studies proved that this site among the most used social sites in many Arab countries And the world, as confirmed by previous studies. 
5) Terrorism-related issues are among the top priorities of the media functions of social networking sites, which was confirmed by $52 \%$ of respondents, because of its advantages, in terms of immediate updating of news and information in all fields. This means that terrorism issues spread through the sites and can affect users in a large way, and the countries of the world in general and the Arab countries in particular, suffer from the events of terrorism, and became the focus of public attention, making it a priority of the media functions of social networking sites, as emphasized by the majority of respondents.

6) Most respondents are not of the opinion that social media sites are objective in their coverage of terrorist issues, while only $11 \%$ agree with this view, confirming the potential role that terrorist groups can exploit in promoting their misleading ideas to users.

7) The increased number of followers and interactions with social networking sites have led to the publication and sharing of the content published by terrorist groups, arousing interest and attention, creating a space for the dissemination of ideas and attracting followers and public. These accounts contributed with or without knowledge to the objectives of terrorist groups and their promotion.

8) Social networking sites have contributed to the spread of terrorist group operations. Terrorist operations have limited impact until they are processed by social media sites and transmitted and the unique realm of news, analysis and transport beyond time and space is diffused like wildfire among the members of society.

\section{RECOMMENDATIONS}

Based on the scientific findings of the field study conducted on a sample of users and activists of social networking sites, the researchers make a set of recommendations:

1) Benefiting from the use of interactive capabilities available on social media sites, both from governmental and non-governmental organizations, especially in raising awareness of the dangers of cases promoted by terrorist groups.

2) Linking social media accounts to the real data of the subscribers and making sure of the identities by linking them through the relevant official authorities to provide the service of communication sites or control devices.

3) Identify specialized bodies in Arab and Islamic countries concerned with security analysis of social sites, follow-up accounts of terrorist groups and work to close them and warn of their seriousness.

4) Governments, with community participation, develop programs that accommodate young people and seek to exploit their energies for the benefit of themselves and their countries and protect them intellectually, psychologically and economically, so that they are not easy prey to extremist terrorist groups.

5) Effective societal interest in reducing the spread of terrorism. Indeed, it is not the responsibility of a single entity, but everyone, individuals, organizations and governments, each for its part, should contribute to the fight against terrorism and the exhaustion of its sources.

6) Design Arab websites with meaningful and useful content, focused on awareness, guidance and orientation, with the aim of reducing the destructive ideas conveyed and promoted by extreme social Web sites in the minds of young people Arabs.

7) Determine the definition of terrorism by the United Nations, to which all States contribute, adopted as a recognized international law, so that terrorism does not remain a rubbery concept, interpreted each as they see fit and used as a projected sword against any dissenting opinion.

\section{SOURCES OF FUNDING}

None.

\section{CONFLICT OF INTEREST}

None. 


\section{ACKNOWLEDGMENT}

None.

\section{REFERENCES}

[1] Shaibat Internet, location: http://www.socialbakers.com// At 3-1-2016. The entry date for the site is $1 / 5 / 2017$.

[2] Al-Serfi, Mohamed Abdel Fattah. Scientific Research Applied Guide for Researchers، (Wael Publishing and Distribution House, Jordan, Oman، 2002) ، P. 115.

[3] Mohamed Abdel Fattah Al-Serafi, Applied Guide to Researchers, Previous Reference, p. 115.

[4] Sheriff Abdullah Mohammed, Scientific research methods، (Radiation Library, Cairo, 1996) P. 123.

[5] The researchers were unable to view all previous scientific studies, due to compliance with the specific conditions for participation, and there are many previous studies in this field.

[6] Amin, Reza Abdul WawąD Social networking sites and their use in introducing the Prophet MuhammadField Study BaNoBased on The Theory of Cultural Development, Arab Journal of Media and Communication, Riyadh: Saudi Media and Communication Society, Issue 17, May 2017, p. 61.

[7] Rabah, sadiq, the role of critical thinking in the rationalization of dealing with rumors on social networks, Arab Media and Communication Magazine, Riyadh: Saudi Media and Communication Society, Issue 17, May 2017, p. 99.

[8] Abdul Rahman, Faten, Arab Media and Communication Magazine, Riyadh: Saudi Media and Communication Society, Issue 17, May 2017, p. 159.

[9] Kafi, Mohammed Abdul Wahab al-Faqih, Al-Salhi, Hatem Ali, Arab Media and Communication Magazine, Riyadh: Saudi Media and Communication Society, Issue 17, May 2017, p. 273

[10] Hassan Qatim Tamah al-Mutairi, Political Uses of The Social Media Site "Twitter" by Kuwaiti Youth, Master's Thesis, Unpublished, Amman: Middle East University, April 2013.

[11] Mubarak Zoda, The Role of Social Media in Public Opinion Industry: The Tunisian Revolution as a Model, Master's Thesis, Unpublished, Algeria: Hajj Lakhdar University, Batna, 2012.

[12] The role of social media sites in motivating Jordanian citizens to participate in the mass movement: a field study, a paper introduction to the 17th Scientific Conference entitled: Culture of Change, Amman: University of Philadelphia, November 2012.

[13] Nasreddine Laiadi, Youth in the UAE and Virtual Networks Approach to Representations and Uses: Survey, Journal of Ideas and Horizons, University of Algiers, Issue2, 2011, p. 65.

[14] Taher Hassan Abu Zeid, The Role of Interactive Social Sites in Guiding Palestinian Public Opinion and Its Impact on Political Participation: Field Study, Master's Thesis, Unpublished, Gaza: Al-Azhar University, 2012.

[15] Web topic link: http://www.assakina.com/news/news2/35942.html\#ixzz4MDRuiToUAnd access the site on $1 / 7 / 2017$.

[16] Bullas, J.: 33 Social Media Facts and Statistics You Should Know in 2015, Accessed on 10 September 2016, from: $\quad$ http://www.jeffbullas.com/2015/04/08/33-social-media-facts-and-statistics-you-should-know-in2015/\#iGlDfYyGfhb4RdEb.99

[17] Heba Shaheen, (2014), the social and security responsibility of the media in dealing with terrorism issues: an applied study of the Republic, the media elite and security, a research paper presented to the Conference on the Role of The Media in Addressing the Phenomenon of Terrorism, Riyadh: Nassf University of Security Sciences, p. 14.

[18] Abdel Hamid, Mohammed, Online Communication and Media, i2, Cairo: The World of Knowledge, 2017, p. 206.

[19] Iman Bakhoush, Hussam al-Din Marzouki: Web 2.0 Social Networks and New Media, A Supplementary Memorandum for a bachelor's degree, Deanship of the Faculty of Arts, Humanities and Social Sciences, 
Department of Media and Communication Sciences, Audiovisual Specialty, Baji Mukhtar University, 2009, p. 35-36.

[20] Khaled bin Abdullah al-Hilweh, the new media and its influences in the formation of public opinion, previous reference, p. 12-13.

[21] Fahad Abdul Rahman Al-Shamiri, Media Education: How do we deal with the media? previous reference, $p$. 183.

[22] Al-Meqdadi, Kazem International and new media and the fourth power crackOsama Publishing and Distribution House, Amman, 2013, p. 226.

[23] Dna, Abdel Malek, Development of Communication Technology and The Globalization of Information and Information, Modern University Office, Cairo, 2005, p. 75.

[24] Rothenberger, Liane, (2012), Terroist Groups: Using Intemet and Social Media eor Dissemi-nang Ideas, New Tools eor Promoting Political Change, Romanian Journal Of Communication an Public Relation, Vol.14, No.3,12, P.8.

[25] Turki bin Saleh Abdullah al-Haqbani, (2006), the extent to which the security media contributes to the treatment of terrorist tahera: a study of a content analysis of a number of local saudi daily newspapers during the period from 1/1/1425 H to 1/6/1425 H, Nayef University of Security Sciences, Graduate Schools, p. 57.

[26] Taha, Najla Abdel Fattah (2015). The role of the media in solving contemporary issues (terrorismcybercrime - issues of globalization), Egypt, Alexandria, University Education.

[27] Al-Ani, Amer And Hab. (2013) Media and its role in addressing the phenomenon of terrorism and the attitude of resistance, Amman: Al-Hamid Publishing House.

[28] Al-Dulaimi, Abdul Razzaq (2010), Propaganda and Terrorism, Jordan, Amman: Ibn Jarir's House for Publishing and Distribution, p. 180.

[29] Carat, Mohammed (2014), Witness the mother of an accomplice in the media's use of terrorism, research published in the magazine Arab Broadcasting Union, Issue 4.

[30] Nafell, Nezhat Mahmood (2002), U.S. Propaganda Trends on International Terrorism, Ph.D., (unpublished), University of Baghdad: Faculty of Media, p. 80.

[31] Arab Observatory for Extremism and Terrorism, website, http://arabobservatory.comThe website is on the website: $1 / 7 / 2017$.

[32] Khaled bin Abdullah al-Hilweh, the new media and its influences in the formation of public opinion, previous reference, p. 4

[33] Link to published material: http://www.assakina.com/news/news2/35942.html It was entered on 1 July 2017.

[34] Hassan, Ayman, Online Extremism via Social Media, European Centre for Counter-Terrorism Studies.

[35] Terrorist retreats from self-detonating at The Mall of Shahir in Maadi, Uae Newspaper Al-Watan, Issue 2201, Saturday 7/10/2017, p1

[36] One hundred young Egyptians and both sexes promoted misguided ideas that were far-reaching and religious, and admitted after their arrest that their main source of information for these practices was the Internet.

[37] Al-Dinani, Abdul Malik, Internet media functionI1, (University Publishing House, Beirut, 2001)211. 